Research Article

\title{
Muamma (conundrum) of Riba (Interest and Usury) in Major Religions in General and
} Islam in Particular

\author{
Dr Ahmad Khalid Khan', Dr Omar Abdullah Al Aboud², Dr. Syed Mohammad Faisal ${ }^{3}$ \\ ${ }^{1,2,3}$ Assistant professor Department of Accounting, Faculty of Administrative Sciences,Jazan University, \\ Kingdom of Saudi Arabia
}

Abstract: Author did courage to undertake this project with his limited knowledge of Religion, therefore, he seek apology in advance with the readers if any mistake has been committed. This paper has no religious relevance rather author has strived to uplift the pride of Interest and rent by making study in different major religion. The paper entitled, "Muamma (conundrum) of Riba (Interest and Usury) in Major Religions in General and Islam in Particular" It is an attempt to study the indication given by the religion that why it is haram. Interest is a very interesting thing; almost in all major religion Riba (Interest and Usury) is Haram including Judaism, however one side in Judaism, the Torah and Talmud encourage the granting of loans if they do not involve interest, on the other hand the halakhah [applicable Jewish law] regarding free loans apply only to loans made to other Jews but it is permissible to make loans with Riba (Interest and Usury) to nonJews.

Yet Riba (Interest and Usury) is Haram in most of the major religion because it disturbs the social fabric, it perturbs the connection which people share, which can facilitate to form an ethnically rich and in a social context cohesive community, Honestly speaking Riba (Interest and Usury) is not only the perpetrator for it, but Riba (Interest and Usury) is one of the cause for it.

On the other hand, where the purpose is for utilization when one has for some cause or other gone astray his earnings, to insist a fixed return where no homecoming is produced is frequently considered as iniquitous. Especially so if the collateral demanded is the house in which the borrower lives or land from the prospect turn out of which he expects to pay back the loan. All the way through the era, currency providers have used the first type of case to defend their business. Ironically it is their appliance of it to the second set of circumstances that twisted the ground for the second type of spat.

Nevertheless, by the last part of the thirteenth century a number of causes emerged which greatly destabilized the influence of the Orthodox Church. In due course, the reformist faction, led by Luther (1483-1546) and Zwingli (14841531), approved to the charging of Riba (Interest and Usury) on the entreaty of human limitation

Key words - Interest, Usury, Haram, Halal, Riba

\section{Prologue}

Interest is a very interesting thing; almost in all major religion, Riba (Interest and Usury) is Haram including Judaism, however one side in Judaism, the Torah and Talmud encourage the granting of loans if they do not involve interest, on the other hand the halakhah [applicable Jewish law] regarding free loans apply only to loans made to other Jews but it is permissible to make loans with Riba (Interest and Usury) to non-Jews.

Yet Riba (Interest and Usury) is Haram in most of the major religion because it disturbs the social fabric, it perturbs the connection which people share, which can facilitate to form an ethnically rich and in a social context cohesive community, Honestly speaking Riba (Interest and Usury) is not only the perpetrator for it, but Riba (Interest and Usury) is one of the cause for it.

People legal inference of all theories of Riba (Interest and Usury) are based on that money has been treat as an article of

trade. It is, therefore, squabble that just as a merchant can sell his article of trade for a higher price than his expenditure, he can also sell his money for a higher price than its face value, or just as he can rent his property and can charge a charge against it, he can also let somebody use his money and can claim Riba (Interest and Usury) thereupon.

Further, in order to understand the case that stands for Interest, it is vital to examine the points of borrowing and lending. When the reason of have a loan of is to put in a project and create revenue, it appears rational for the provider of loan to demand for go halves in the return. For convenient, the incentive (interest) is fixed in advance; and for the protection of the capital guarantee is specified. Therefore, charging of a realistic interest, agreed upon by both sides, is seen by many to be absolutely valid.

On the other hand, where the purpose is for utilization when one has for some cause or other gone astray his earnings, to insist a fixed return where no homecoming is produced is frequently considered as iniquitous. Especially so if the collateral demanded is the house in which the borrower lives or land from the prospect turn out of which he expects to pay back the loan. All the way through the era, currency providers have used the first type of case to defend their business. Ironically it is their appliance of it to the second set of circumstances that twisted the ground for the second type of 
spat.

Nevertheless, by the last part of the thirteenth century a number of causes emerged which greatly destabilized the influence of the Orthodox Church. In due course, the reformist faction, led by Luther (1483-1546) and Zwingli (1484-1531), approved to the charging of Riba (Interest and Usury) on the entreaty of human limitation. As per Encyclopedia Britannica,

"In Old English law, the taking of any compensation whatsoever was termed usury. With the expansion of trade in the 13th century, however, the demand for credit increased, necessitating a modification in the definition of the term. Usury then was applied to exorbitant or unconscionable Riba (Interest and Usury) rates. In 1545 England fixed a legal maximum interest; any amount in excess of the maximum was usury. The practice of setting a legal maximum on Riba (Interest and Usury) rates was later followed by most states of the United States and most other Western nations."

Consequently, beginning in the mid-sixteenth century, the embargo on usury (in the old sense) was lawfully disinterested in all Western countries. The milieu, in which it took place, as evidenced by the above quote, is noteworthy. Today, just about ubiquitously barring few, charging and paying Riba (Interest and Usury) is legal, no matter how much, and it is acceptable both in theory and practice. Their logic and theories, including time preference, liquidity preference, deposit mobilization, scarcity of capital, and rationing capability of interest, and proves them untenable.

\section{Definition of the word Riba, Interest, Usury,}

Riba apparently means 'to grow; to increase.' Strictly, it signifies the amount that lenders take delivery of from a borrower at a fixed rate in glut of the principal. It is of two kinds.

- Riba Nasi'a - charging interest on money lend.

- Riba Fadal - demanding somewhat of greater worth in exchange for giving inferior of the alike article or poorer in quality.

In English it is usually translated as "Interest" or "Usury"

Interest: - Extra amount charged on the money lent at a particular interval and particular rate, or for interruption in the repayment of a debt.

Usury: -The act of charging high and unreasonable rates of interest on money lent

\section{Objective of the Paper}

- To identify with the logics given by the people who uses Riba in a more comprehensive and plausible manner.

- To cram the clue given by all Major Religions in regards to Riba.

- To learn the often raised objections against Riba in Islam

- To learn the signs given by Islam or Al Quran in relation to Riba.

- $\quad$ To recognize the meaning of Riba (Interest and Usury).

- Try to adapt why Riba (Interest and Usury) is Curse for the society.
- To comprehend the wisdom behind all the major religion including Islam considers that Interest as Haram.

\section{Frequently Asked Question Against Riba:-}

- If a person by profession deals with interest, does this mean that there fast will not be accepted?

- If Ulema are so adamantly against interest and they feel that an alternative exists, why don't they erect a countersystem that is free of interest, and thus demonstrate what they preach?

- Imposing the rules of interest all the way through the government is in opposition to the Sunnah of the Holy Prophet.

- In the Quran, Allah urges believers to give Him "a loan" which He promises to return increased manifold. Is this not a form of interest?

- Interest is permissible if it is acceptable to all the parties making the transaction.

- Interest offsets the loss of value of currency due to inflation.

- Interest on manufacturing or marketable loans does not plunge in the group of riba.

- It is pointless to strive for an interest- free economy in a society that is not truly or completely Islamic.

- Our times are different from the times of the Holy Prophet. Commercial interest did not exist in the days of the Prophet.

- Riba is the late-return penalty levied on the loan returned after the due date

- Since banks deal in trade and business, what they give or take is profit (which is permitted by Allah) not riba.

- Surat Aal-e-Imran (3: 130), it is prohibited to acquire interest by doubling or quadrupling the principal amount, it means that to certain extent of interest is acceptable.

- The Islamic Shariat Court verdict comparing bank interest with riba is not practical. It is bound to stir anarchy in the country.

- The verses about interest in Surat Al-Baqarah related to the poor and orphans, not to trader and entrepreneurs, who make use of money frequently for investing in a company.

(Source: collected and compiled by the researcher)

\section{Prohibition of Riba (Interest and Usury) in Major Religions}

\section{Prohibition of Riba (Interest and Usury) in Judaism}

If one has charged interest or taken increase-- shall he then live? He shall not live! If he has done any of these abominations, he shall surely die; his blood shall be upon him. -- Prophet Ezekiel (18:13)

He does not put out his money at interest, nor does he take a bribe against the innocent. He who does these things will never be shaken. --David (Psalm 15:5)

He who increases his wealth by interest and usury gathers it for him who is gracious to the poor. --Solomon (Proverbs 28:8)

You shall not charge interest to your brother--interest on money or food or anything that is lent out at interest. --Moses (Deuteronomy 23:19)

One who lends money on usury cannot be regarded as 


\section{Dr Ahmad Khalid Khan et al / Muamma (conundrum) of Riba (Interest and Usury) in Major Religions in General and Islam in Particular}

reformed until he tear up his account-books and effect a complete reformation.

(Talmud, Tractate Sanhedrin II.--JUDICIAL PROCEDURE: "Those who are Eligible and those who are Ineligible as Judges or Witnesses" III.3. M. T. V. 2.)

He who lives by usury in this world shall not live in the world to come. (Midrash, Exodus Rabba 31).

There were also some who said,

"We have mortgaged our lands and vineyards and houses, that we might buy grain because of the famine."

There were also those who said,

"We have borrowed money for the king's tax on our lands and vineyards... and indeed we are forcing our sons and our daughters to be slaves, and some of our daughters have been brought into slavery. It is not in our power to redeem them, for other men have our lands and vineyards."

And I became very angry when I heard their outcry and these words. After serious thought, I rebuked the nobles and rulers, and said to them,

"Each of you is exacting usury from his brother."

So I called a great assembly against them....

"Please, let us stop this usury! Restore now to them, even this day, their lands, their vineyards, their olive groves, and their houses, also one percentof the money and the grain, the new wine and the oil, that you have charged them."--Nehemiah $(5: 3-7,10-11)$

Note how Nehemiah was utterly appalled about even $1 \%$ interest! This would be considered charity by today's banking standards! This blows the argument of many self-proclaimed Jews \& Christians who claim, along with many Muslims, Buddhists, \& Hindus, that usury is "excessive interest," while "regular interest" is okay. Usury is interest is usury is interest: there is no difference.

Lo and Behold, the very Garden of Eden story is about lending at interest.

\section{Prohibition of Riba (Interest and Usury) in Christianity}

Forgive us our debts, even as we forgive our debtors. --Jesus (Matthew 6:12)

And if you lend to those from whom you hope to receive back, what credit is that to you? For even sinners lend to sinners to receive as much back. But love your enemies, do good, and lend, hoping for nothing in return; and your reward will be great, and you will be sons of the Most High. -- Jesus Christ (Luke 6:34-35)

Jesus said, "If you have money, do not lend it at interest. Rather, give to someone from whom you will not get it back." (Gospel of Thomas 95)

Owe no person anything, except to love one another. -Apostle Paul (Romans 13:8)

He who takes interest for a loan of money acts unjustly for he sells what does not exist. It is wrong in itself to take a price (usury) for the use of money lent, and as in the case of other offences against justice, one is bound to make restitution of his unjustly acquired money. --Saint Thomas Aquinas
Any "Christian" businessmen theologians erroneously state that the New Testament is silent about forbidding interest. But the New Testament clearly goes even a step beyond forbidding interest, telling us to lend, expecting nothing at all in return. On top of that, we are to not even owe. On top of that, we are to forgive all debts!

Central to Jesus' message is that debt and sin are one and the same.

Lo and Behold, the very Garden of Eden story is about lending at interest.

\section{Prohibition of Riba (Interest and Usury) in Islam}

The word "Riba" is used in the Holy Quran 8 times. In $30: 39,4: 161,3: 130,2: 276,2: 278$ and 3 times in 2:275. The Quran says

"Those who devour usury will not stand except as stand one whom the Evil one by his touch Hath driven to madness. That is because they say: "Trade is like usury," but Allah hath permitted trade and forbidden usury. Those who after receiving direction from their Lord, desist, shall be pardoned for the past; their case is for Allah (to judge); but those who repeat (The offence) are companions of the Fire: They will abide therein (for ever)." (Quran 2:275)

"O ye who believe! Devour not usury, doubled and multiplied; but fear Allah. that ye may (really) prosper." (Quran 3:130)

"O ye who believe! Fear Allah, and give up what remains of your demand for usury, if ye are indeed believers. If ye do it not, Take notice of war from Allah and His Messenger. But if ye turn back, ye shall have your capital sums: Deal not unjustly, and ye shall not be dealt with unjustly." (Quran 2:278-279)

Quran does not only say that riba is a sin but also reveals in the holy book Almighty and his Prophet Muhammad (pbuh) will declare a war against those who are involve in this sinful economic activity.

Riba is the seventh major sin categorize by Prophet Muhammad (pbuh)

\section{"Volume 8, Book 82, Number 840:}

Narrated Abu Huraira: The Prophet said, "Avoid the seven great destructive sins." They (the people!) asked, "O Allah's Apostle! What are they?" He said, "To join partners in worship with Allah; to practice sorcery; to kill the life which Allah has forbidden except for a just cause (according to Islamic law); to eat up usury (Riba), to eat up the property of an orphan; to give one's back to the enemy and freeing from the battle-field at the time of fighting and to accuse chaste women who never even think of anything touching chastity and are good believers."

Some Muslims may argue that only the taking of interest is prohibited. But one Sahih Hadith says " Hazrat Jabir (RA) has reported that the Messenger of Allah cursed the devourer of usury, its payer, its scribe and its two witnesses. He also said that they were equal (in sin)." (Mishkat-ul-Masabih)

Though there are many hadith which condemn riba (interest) but these two are sufficient for now.

\section{Prohibition of Riba (Interest and Usury) in Hinduism}

A Brâhmana and a Kshatriya shall not lend anything at 


\section{Dr Ahmad Khalid Khan et al / Muamma (conundrum) of Riba (Interest and Usury) in Major Religions in General and Islam in Particular}

interest... 'He who acquiring property cheap, gives it for a high price, is called a usurer and blamed among those who recite the Veda.'

'God weighed in the scales the crime of killing a learned Brâhmana against the crime of charging interest; the slayer of the Brâhmana remained at the top, the charger of interest sank downwards.' (Vasishtha, The Sacred Laws of the Aryas, Part II, Chptr 2, vs 40-42)

A person of yoga obtains everlasting peace by abandoning the rewards of action.

The person ignorant of yoga, selfishly attached to reward, remains

bound.

(Bhagavad Gita 5:12. This verse, in fact, is representative of the very theme of the Bhagavad Gita)

Note how the Hindu Sage Vasishtha considered charging interest a crime worse than murder. Real and blatant slavery of men, women and children, is rampant in India because of India's disregard for her own Hindu principles.

Also, as in Christianity, we see in the Bhagavad Gita that later Hinduism goes even a step beyond forbidding charging interest, imploring us over and over and over to do nothing for the sake of reward, give expecting nothing in return, but simply to do for the sake of doing.

\section{Prohibition of Riba (Interest and Usury) in Buddhism}

"One discerns wrong livelihood as wrong livelihood, and right livelihood as right livelihood. And what is wrong livelihood? Scheming, persuading, hinting, belittling, and charging interest. This is wrong livelihood." --Siddharta Gautama Buddha in his sermon on the Eightfold Path (Majjhima Nikaya Suttra 117)

\section{Prohibition of Riba (Interest and Usury) in Greek Philosophy}

"No one shall deposit money with anyone he does not trust, nor lend at interest, since it is permissible for the borrower to refuse entirely to pay back either interest or principle."

--Plato (Laws)

The trade of the petty usurer is hated with most reason: it makes a profit from currency itself, instead of making it from the process which currency was meant to serve. Their common characteristic is obviously their sordid greed.... Hence of all the kinds of wealth acquisition this one is the most unnatural. --Aristotle (Politics)

\section{Why Riba (Interest and Usury) curse for the society}

Once interest is accepted as the integral element of business and finance, it begins to eat into the fabric of human society. Even a passing glance at the myriads of miseries with which it afflicts the society is enough to appreciate the wisdom.

Interest clusters assets in few hands: - because interest is almost risk free way enlarging capital if you already have means, this occupation to gather assets into the few hands or of a minority, which has possibly in a social context disparaging.

Interest bring in insecurity into the money-making system:- If populace are give somebody the loan of or funds to others, but it is unchained to a material source and based on the anticipation that not each one will try to get back their fluid property at the same time, the so called liquidity ratio which allows moneylenders to not have to hold all of the currency they have lent in liquid form, this can commence economic unsteadiness into the system.

Interest can reason for more spending that afterward can prove to be life-devastate: - If inhabitants are given the choice of scrounging against prospect earnings not including eloquent what those expected earnings are, people may consume in excess of. A huge number of inhabitant's existence has been shattered by and many suicides take place because of debt, credit card debt and etc.

There is elongated list of reasons why Riba is considered as curse for the humanity: -

Bottling up the Supply of Capital, Business Risk, Capitalist Control over Institutions, Individuals and Key Sources of National Income, Damage to Collective Social Development, Excessive Profit-Making, Exploitation of the Poor, Extremist Reactions: Communism, Friction in International Relations, Instability in Market Demand and Supply, Intractable Complexities, Marginalization of National Welfare Projects, Murder of Civility and Well-being, Negative Effects on Savings and Investment, Negative Impact on the Performance of Capital in Small Businesses, Perpetual Deficit in National Income, Price Hike, Devaluation and Inflation, Priority of Capital over Human Labour, Reduced Circulation of Wealth, Restriction on Production, Rise of Greed and Selfishness, Rise of Rent and Fare, Rise of Unemployment, Social Instability, The Supreme Loss, Tyranny of Taxes, Usurpation of Earned Income.

\section{Riba (Interest and Usury) is twelfth major sins in Islam}

Allah in the Quran and by His Messenger (SAW) in the Sunnah (practice of the Prophet), have forbidden some of the acts which therefore considered as major sins and which have been made clear by the actions of the first righteous generation of Muslims, the Companions of the Prophet (SAW). The list of sins (only fifteen) is as follows:-

1. Associating anything with Allah

2. Murder

3. Practicing magic

4. Not Praying

5. Not paying Zakah

6. In Ramadan not fasting without excuse

7. Physically and financially sound and not performing Hajj

8. Disrespect to parents

9. Abandoning relatives

10. Fornication and Adultery

11. Homosexuality(sodomy)

12. Interest (Riba)

13. Wrongfully consuming the property of an orphan

14. Lying about Allah and His Messenger

15. Running away from the battlefield

Why Riba (Interest and Usury) is considered Haram in Religion

Dishonesty due to Riba (Interest and Usury) in the society, the through morally bad of usury are clear and evident. Caching of means broaden the fissure among the affluent and the deprived. Paucity is a trouble that can disgrace and put down its sufferers, corrode his values and wipe out his ethics. These in turn go ahead to spitefulness, robbery and slaughter. Those openly accountable for devastating the social stability are the hoarders, who summative assets and thus it was out of stock to 


\section{Dr Ahmad Khalid Khan et al / Muamma (conundrum) of Riba (Interest and Usury) in Major Religions in General and Islam in Particular}

those who needed it. The total crumbling of the social fabric can precipitate a civil war and further a world war which brings with it only death and destruction.

In Islam Riba (Interest and Usury) can be adjudicate from the fact that not only the person who charges it and the one who pays it are cursed, but even those who write the documents and bear witness to the transaction are fated although the latter two have no vigorous part in the deal. They have been destined for their mere assistance in the matter of interest. Thus, we learn that even assistance in the deal in which Riba (Interest and Usury) is involved is an invitation to the Curse and Wrath of Allah.

The reason for such strictness in the matter of Riba (Interest and Usury) is that Islam wants to create a society that is founded on sorority, compassion, self-sacrifice and forgo. If someone is in need of money, the rich should fulfill his needs for the sake of Allah's Pleasure or offer him an advance not including interest. As against the Islamic system, this system of Riba (Interest and Usury) is based on self-centeredness, abuse and containment.

In the interest-navigate societies, the affluent ones are not tending to collaborate with the deprived for the sake of Allah. All they are anxious with is their own interest. Their desire and gluttony are not reduced in the least appraise even after exhausting the last drop of the blood of the poor. This is the motive why Islam has forbidden Riba (Interest and Usury) of every kind and considered it illegal, no matter whether the loan is for the personal need or profitable requirements.

\section{Wisdom behind Haram of Riba (Interest and Usury) in Religions}

Money has dissimilar nature and therefore they can be extravagance in your own way. The fundamental point of dissimilarity is Money has no inherent usefulness. It cannot be make use of in direct execution of individuals' desires. It can only be worn for attain a number of merchandise or services. The stock can be of dissimilar traits at the same time as currency has no eminence except for that it is an intermediate of swap or a gauge of worth. Consequently, all the piece of money of the same quantity, are hundred per cent equal to each other. A previous and grimy note of SR100/= has the same worth as a brand new note of SR.IO0/=.

\section{Wisdom behind Halal of Trade, Rent}

In merchandise, the dealings of vending and procuring are affected on a recognized scrupulous product.If $\mathrm{Mr}$. $\mathrm{X}$ has procure a particular purse by investigative it, and vendor has approved, he deserves to take delivery of the same. The peddler cannot coerce him to take the delivery of another purse, despite the fact that of the same brand or value. Money, on the contrary, cannot be pin-pointed in a transaction of exchange. If $\mathrm{Mr}$. $\mathrm{X}$ has purchased a purse from Mr. $\mathrm{Y}$ by showing him a particular note of Rs.100/-, Mr. X still can pay a different cash of same value to Mr. Y.

\section{Epilogue}

Conclusively, it is command in religion to drop what remains of interest. It is clearly and categorical ordered in every religion to do not indulge in Riba. It does not point out persons from whom interest may not be taken; moreover, it subsumes all forms of interest. It is said that if the nonpayer is in straitened conditions, there must be deferment till the time of relieve. It is incorrect to construe from this that the defaulter in such circumstances has to be a deprived human being.

It may be the case of a manufacturer or an entrepreneur who desires funds and is not able pay it back for the time being. In any case, relieve would apparently be for the one who could be anticipated to reimburse the funds borrowed. As for the deprived and the orphans, it is unstated that their debts would be written off as alms as enjoined in the every religious scripture.

In verse 279 of Surah al Baqarah-one of the verses dealing with the prohibition of interest-it is stated: Wrong not and you shall not be wronged. Consequently the justification for the prevention of Riba is that through it humanity is wronged. Do the entrepreneur and manufacturer who take loans from moneylenders pay them off from their own pockets? On the converse, interest as a cost factor is included in the price of the goods. Thus the burden ultimately falls on the consumers. And among them are both, the rich as well as the poor.

Secondly what is the assurance that the scrounger manufacturer or an entrepreneur is bound to create revenue and that would be plenty to recompense interest in adding together to the amount of advance? Is it fair that while the providing party's (i.e. the moneylender's) profit is fixed the scrounger may be unable to find all and yet be indebted to pay back a sum well in surplus of the advance? In addition, Moneylenders make no compromises of interest rate in cases of non-trade mortgages. A most important piece of the government's loans may be spent in the defense sector or in payment of salaries. Are moneylenders any compassionate in such cases? Likewise, the average inhabitant may scrounge from a Moneylender for house or car financing or even for wedding arrangements. Moneylenders are no less rigorous than Shylock in exacting their pound of flesh. In fact, it is sad to observe that the terms of loan are often far more flexible for businessmen who borrow to make money.

Last but not least " By the time. Indeed, man is in loss. Except those who believed and did righteous deeds, and advised each other to truth, and advised each other to patience". (Quran 103:1, 2, 3)

You are the best nation produced [as an example] for mankind. You enjoin what is right and forbid what is wrong and believe in Allah. (Quran 3:110)

\section{Reference}

[1] AAOIFI. (1996) Accounting and Auditing Standards for Islamic Financial Institutions. Manama, Bahrain: Accounting and Auditing Organization for Islamic Financial Institutions.

[2] Abdelgader, A.E. (1994) Accounting postulates and principles from an Islamic perspective. Review of Islamic Economics. 3 (2): 1-18.

[3] Aboud, Syed, Khan, (2018), "Study of Managerial Decision Making Linked to Operating and Financial Leverage", International Journal of Accounting and Finance Research, Vol. 7 ,No 1 ,2018 , pp.139-143 doi:10.5430/afr.v7n1p139

[4] Adnan, M.A. and Gaffikin. (1997) The Shariah, Islamic banks and accounting concepts and practices. Proceedings of the International Conference 1: Accounting Commerce and Finance: The Islamic Perspective. Sydney, Australia. 
[5] Ahmad, M. (1995) Business Ethics in Islam. Islamabad : IIIT (Pakistan)

[6] Ahmad, S.F. (1988) The ethical responsibility of business: Islamic principles and implications. Paper of the Seminar on Islamic Principles of Organizational Behavior. Virginia, USA.

[7] Ahmad, S.N.S. and Hamad, M. (1992) Accounting Standard and Islamic Banks Accamedia. 11 (1): 46-61.

[8] Al-Faruqi, I.R. (1992), Al-Tawhid: Its Implications for Thought and Life, Herndon, Virginia: International Institute of Islamic Thought.

[9] Al-Qardhawi, Y. (1988) Fiqh al-Zakat (The Law of Zakat) Lahore: Al-Faisal Publishing.

[10] An-Nawawi, Y.S. Syarah Hadits Arba'in (1997): 41 Hadits tentang Kaidah-Kaidah Agung Islam serta Penjelasannya (41 Prophetic explanations regarding the main Islamic principles.). Transl by Murtaho $\mathrm{H}$. and Salafuddin A.J. Solo: Al-Qowam.

[11] Anwar, M. (1987) Islamic economic methodology. Paper of the Seminar on Islamic Economics. Washington, USA.

[12] Arnold, P.J. and Cooper, C. (1999) A tale of two classes: The privatization of Medway Ports. Critical Perspectives on Accounting. 10 (2): 127-152.

[13] Baydoun, N. and Willet, R. (1997) Islam and accounting: ethical issues in the presentation of financial information. Accounting, Commerce and Finance: The Islamic Perspective. 1 (1): 1-24.

[14] Baydoun, N. and Willet, R. (2000) Islamic corporate reports. Abacus. 36 (1): 21-91.

[15]Briloff, A. (1990) Accounting and society, a covenant desecrated. Critical Perspectives on Accounting. 1(1): 530 .

[16] Chapra, M.U. (1992) Islam and the Economic Challenge. Herndon, Virginia; IIIT.

[17]Chen, R. (1975) Social and financial stewardship. The Accounting Review. 61(1): 1-21.

[18] Clark, F., Craig, R., and Hamid, S. (1996) Physical asset valuation and zakat: insights and implications. Advances in International Accounting. 9: 195-208.

[19]FASB. (1996) Statement of Financial Accounting Concepts. Norwalk, Connecticut: Financial Accounting Standard Board.

[20] Gambling, T and Karim, R.A.A. (1991) Business and Accounting Ethics in Islam. London: Mansell Publishing Ltd.

[21] Gray, R., Owen, D and Adams, C. (1996) Accounting and Accountability: Changes and Challenges in Corporate Social and Environmental Reporting. London: Prentice Hall.

[22] Gray, R.H. (1994) Accounting, the accountancy profession and the environmental crisis (or can accountancy save the world?) Meditari: 1-51.

[23] Hameed, S. (2000a). The need for Islamic Accounting: Perception of Its Objectives and Characteristics by
Malaysia Accountants and Academics. Ph.D. Thesis. University of Dundee.

[24] Hameed, S. (2001) Islamic accounting - accounting for the new millenium? Paper of the Asia pacific Conference1-Accounting in the New Millenium. Kota Bahru, Malaysia.

[25] Haniffa, R. and Hudaib, M. (2001) A conceptual framework for Islamic accounting: The Shari'a paradigm. Paper of the International Conference on Accounting, Commerce and Finance: The Islamic Perspective. New Zealand.

[26] http://biblehub.com/proverbs/28-8.htm

[27] http://complementarycurrency.org/ccLibrary/materials/W hy\%20do\%20religions \%20prohibit\%20usury.htm

[28] http://hadith.al-islam.com/ English Translations, (Sahih Bukari, Sahih Muslim)

[29] http://users.bart.nl/ abdul/article4.html\#_Toc85909454

[30] http://www.Accountingformanagement.com/double_entry _bookkeeping.htm

[31] http://www.answering-christianity.com/yahya_ahmed /riba.htm

[32] http://www.tafsir.com/Default.asp

[33] http://www.usc.edu/dept/MSA/fundamentals/hadithsunna h/ Quran, Arabic Text

[34] https://en.oxforddictionaries.com/definition/interest

[35] https://sites.google.com/site/livingwithoutmoney/Home/w hat-the-world-s-religions-philosophers-say-about-thecrime-called-banking

[36] https://sites.google.com/site/livingwithoutmoney/Home/w hat-the-world-s-religions-philosophers-say-about-thecrime-called-banking

[37] https://studentsofknowledge.org/business-transactions/ question-162-interest-bearing-loanmortgage-from-bank/

[38] https://www.britannica.com/topic/usury

[39] https://www.coursehero.com/file/p4nldhi/Interest-moneypaid-regularly-at-a-particular-rate-for-the-use-of-moneylent-or/

[40] https://www.google.com.sa/search?safe=strict $\& q=$ what $+\mathrm{i}$ $\mathrm{s}+$ the+meaning+of+usury+and+interest+in+judaism\&spel $1=1 \&$ sa $=$ X\&ved=0ahUKEwjKop7Tg6XUAhWKbhQKHc IoC1UQvwUIISgA\&biw=1152\&bih=635

[41] https://www.imamreza.net/eng/imamreza.php?id=7288

[42] https://www.quora.com/Why-is-charging-interest-usuryforbidden-in-Islam

[43] https://zakirnaikqa.wordpress.com/tag/dr-zakir-naik-oninterest/ 